\title{
Downstream Extent of the N Reactor Plume
}
D. D. Dauble
L. W. Vail
R. M. Ecker
D. A. Neitzel

September 1987

Prepared for the U.S. Department of Energy under Contract DE-AC06-76RLO 1830

Pacific Northwest Laboratory Operated for the U.S. Department of Energy by Battelle Memorial Institute 


\section{DISCLAIMER}

This report was prepared as an account of work sponsored by an agency of the United States Government. Neither the United States Governmentnor any agency thereof, nor Battelle Memorial Institute, nor any of their employees, makes any warranty, expressed or implied, or assumes any legal liability or responsibility for the accuracy, completeness, or usefulnessof any information, apparatus, product, or process disclosed, or represents that its use would not infringe privately owned rights. Referenceherein to any specific commercial product, process, or service by trade name, trademark, manufacturer, or otherwise, does not necessarily constitute or imply its endorsement, recommendation, or favoring by the United States Government of any agency thereof, or Battelle Memorial Institute. The views and opinions of authors expressed herein do not necessarly state or reflect those of the United States Governmentor any agency thereof, or Battelle Memorial Institute.

\section{PACIFIC NORTHWEST LABORATORY operated by BATTELLE MEMORIAL INSTITUTE for the UNITED STATES DEPARTMENTOF ENERGY under Contract DE-AC06-76RLO 7830}

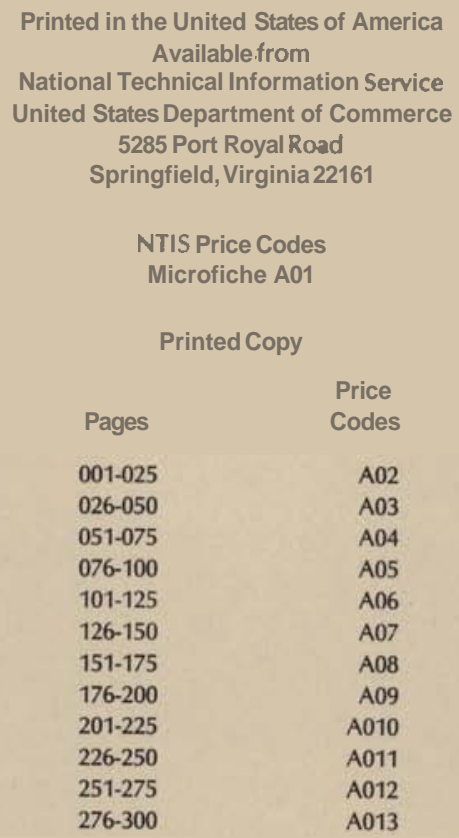


DOMNSTREAM EXTENT OF THE N REACTOR PLUME
D. D. Dauble
R. M. Ecker
L. W. Vail
D. A. Neitzel

September 1987

Prepared for the U.S. Department of Energy under Contract DE-AC06-76RLO 1830

Pacific Northwest Laboratory Richland, Washington 99352 
. ..

1. 
The downstream extent of the $\mathrm{N}$ Reactor thermal plume was studied in response to requests for information from the Washington State Department of Ecology and the U.S. Environmental Protection Agency Region X. W describe the N Reactor plume, discuss the physical factors that affect Columbia River temperatures, and assess the potential for fisheries impacts downstream of N Reactor.

The $\mathrm{N}$ Reactor plume, as defined by the $0.5^{\circ} \mathrm{F}$ isotherm, will extend less than 10 miles downstream at river flows greater than or equal to annual average flows $(120,000 \mathrm{cfs})$. Incremental temperature increases at the OregonWashington border are expected to be less than $0.5^{\circ} \mathrm{F}$ during all Columbia River flows greater than the minimum regulated flows $(36,000 \mathrm{cfs})$. The major physical factor affecting Columbia River temperatures in the Hanford Reach is solar radiation. Because the estimated temperature increase resulting from $\mathrm{N}$ Reactor operations is less than $0.3^{\circ} \mathrm{F}$ under all flow scenarios, it is unlikely that Columbia River fish populations will be adversely impacted. 
$\cdot$ 


\section{ACKNOWEDGMENTS}

The authors extend their thanks to E. M. Greager of Westinghouse Hanford Company for managing this project. Thanks are also extended to K. A. Borgeson of Pacific Northwest Laboratory for editing this report. This work was funded by Westinghouse Hanford Company, PNL Project No. 11999. 



\section{CONTENTS}

SUMMARY ...................... . . . . . . .

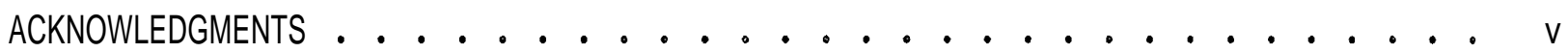

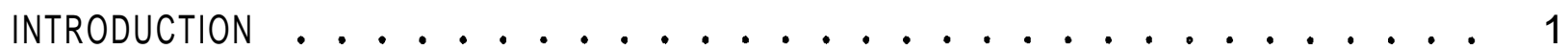

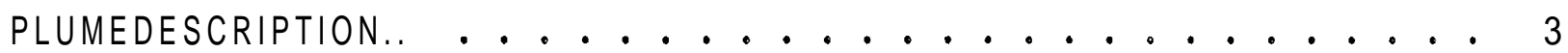
PHYSICAL FACTORS AFFECTING RIVER TEMPERATURE . . . . . . . 7 POTENTIAL EFFECTS OF INCREASED THERMAL LOADING ON DOWNSTREAM FISH POPULATIONS . . . . . . . . . . . 11

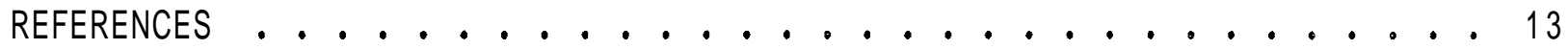

APPENDIX - DESCRIPTION OF THERMAL MIXING REGIMES AND

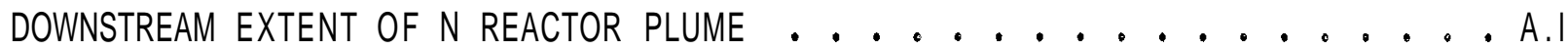



$\underline{\text { INTRODUCTION }}$

The $\mathrm{N}$ Reactor thermal plume, as defined by the $0.5^{\circ} \mathrm{F}$ isotherm, will extend less than 10 miles downstream at river flows greater than or equal to annual average flows $(121,000 \mathrm{cfs})$. Incremental temperature increases at the Oregon-Washington border are expected to be less than $0.5^{\circ} \mathrm{F}$ during all Columbia River flows greater than 36,000 cfs (minimum regulated flows). This assessment is based on the amount of heat discharged to the Columbia River from $\mathrm{N}$ Reactor and the physical factors that influence dissipation of that heat load. Estimations of $\mathrm{N}$ Reactor thermal plume dynamics were previously described for river flows ranging from 36,000 to 351,000 cfs (Ecker, Walters and Thompson 1983). This report provides a summary of that description, a discussion of the physical factors that affect Columbia River temperatures, and an assessment of the potential for fisheries impacts at locations downstream of $\mathrm{N}$ Reactor. A brief description of the model and assumptions used to describe thermal mixing regimes and downstream extent of the plume is attached as an appendix. 


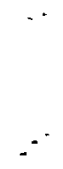

- 


\section{PLUME DESCRIPTION}

The $N$ Reactor thermal plume is well defined and generally very narrow, and discharge temperatures decrease rapidly downstream of the discharge port. The temperature increase in the Columbia River resulting from N Reactor discharge depends on river flow. The rate of mixing is related to Columbia River flow rates, channel geometry (width, depth, islands and bends, etc.), channel bed irregularities (shoots and pools), and variations in flow velocities (cross-sectional and vertical). Large variations in these factors cause the mixing rate to increase.

Initial mixing of the thermal plume near the discharge port is very rapid. Complete vertical mixing occurs within $300 \mathrm{ft}$ downstream of the discharge port. Initial lateral mixing (spreading) of the thermal plume is also very rapid. The width of the thermal plume increases from about $6 \mathrm{ft}$ at the discharge port to about $130 \mathrm{ft}$ at a distance of $50 \mathrm{ft}$ downstream. The rate of spread of the thermal plume after this initial mixing is very slow. The width of the thermal plume $\left(\Delta T>0.5^{\circ} \mathrm{F}\right)$ is only $200 \mathrm{ft}$ at a distance of $1350 \mathrm{ft}$ downstream. At this rate of spreading and assuming the mixing conditions remain constant, complete lateral mixing of the thermal plume across the river would occur within 8.5 miles downstream from the discharge port. However, the presence of islands, bends, and channel crossings within 3 miles downstream of the $\mathrm{N}$ Reactor tends to increase the lateral mixing of the $\mathrm{N}$ Reactor thermal plume, resulting in a reduction of the distance required for total cross-channel mixing. Plume width is also affected by river flows. For example, at a point $300 \mathrm{ft}$ downstream of the discharge, the plume width decreases from $180 \mathrm{ft}$ during low flow conditions (53,500 cfs) to $145 \mathrm{ft}$ during intermediate flow conditions $(78,000 \mathrm{cfs})$.

The highest plume temperatures are found near the discharge port and below a $10-\mathrm{ft}$ depth. There is a rapid longitudinal and transverse decrease in plume temperatures as the thermal plume rises and as mixing occurs downstream from the port. Plume temperatures decrease rapidly at all depths with increasing distance downstream from the discharge port. The greatest decline in near-surface ( $\mathrm{I}$ - $10-\mathrm{ft}$ depth) plume temperature occurs within $150 \mathrm{ft}$ down- 
stream from the discharge port and within $50 \mathrm{ft}$ downstream from the discharge port for bottom (1.1 - $20-\mathrm{ft}$ depth) measurements.

The $N$ Reactor plume does not completely mix laterally until that plume has mixed with the Hanford Generating Project (HGP) plume. However, the HGP thermal plume does not interact with the $\mathbf{N}$ Reactor thermal plume within the National Pollutant Discharge Elimination System (NPDES) mixing zone. The two thermal plumes merge downstream from the $\mathbf{N}$ Reactor mixing zone and during low flows- cannot be distinguished from each other about $3400 \mathrm{ft}$ downstream from the $\mathbf{N}$ Reactor discharge port. The combined width of the two plumes at that point is about $700 \mathrm{ft}$, with a maximum temperature of about $2^{\circ} \mathrm{F}$ above ambient.

We initially used a thermal mixing model to provide information on the downstream extent of the $\mathrm{N}$ Reactor plume. This model assumed the $\mathbf{N}$ Reactor plume was isolated from the HCP plume during mixing (see Appendix).

Calculations of incremental thermal increases to the Col umbia River indicate that the fully mixed $\mathrm{N}$ Reactor discharge will result in a temperature increase of $0.7^{\circ} \mathrm{F}$ to $2.3^{\circ} \mathrm{F}$ when river flows are less than $120,000 \mathrm{cfs}$ (Table 1). Modeled $\Delta T$ s do not decrease at points greater than $10,000 \mathrm{ft}$ downstream of $\mathrm{N}$ Reactor. The modeled temperature increase is reduced at high flows; the $\mathrm{AT}$ is only $0.2^{\circ} \mathrm{F}$ at points greater than $1000 \mathrm{ft}$ downstream when flows are 350,000 cfs (Table 1).

Because modeled temperature increases did not consider additional heat input from the HGP discharge, simple energy balance calculations were also made using the assumptions of complete mixing and no additional sources or sinks of heat in the Columbia River. These calculations provide a better measure of the relative thermal inputs to the river from $\mathbf{N}$ Reactor and the HGP. For example, the $N$ Reactor discharge at 800 megawatts thermal (MWt) will increase the Columbia River temperature by $0.34^{\circ} \mathrm{F}$ at minimum regulated flows of 36,000 cfs (Table 2). However, the HOP discharges an additional 2300 MWt to the river during dual-purpose operation. The combined discharges (3000 MWt) will result in a $1.27^{\circ} \mathrm{F}$ increase in temperature at minimum regulated flows of $36,000 \mathrm{cfs}$, and a $0.37^{\circ} \mathrm{F}$ increase at near-annual average flows of 126,000 cfs (Table 2). 
TABLE 1. Modeled Temperatures ( ${ }^{\circ} \mathrm{F}$ Above Ambient) at Varying Distances Downstream of $t_{\text {ge }}$ N Reactor Outfall for a Range of River
Flows (800 MWt)

\begin{tabular}{|c|c|c|c|c|c|}
\hline \multirow{2}{*}{$\begin{array}{c}\text { Downstream } \\
\text { Distance }(\mathrm{ft})\end{array}$} & \multicolumn{5}{|c|}{ Flow (cfs) } \\
\hline & 36,000 & 54,000 & 90.000 & 120,000 & 350,000 \\
\hline 1 & 9.5 & 9.4 & 9.5 & 9.5 & 6.1 \\
\hline 2 & 9.4 & 9.4 & 9.4 & 9.4 & 5.3 \\
\hline 5 & 9.4 & 9.4 & 9.4 & 9.2 & 4.5 \\
\hline 10 & 9.4 & 9.4 & 9.4 & 8.5 & 3.7 \\
\hline 50 & 8.8 & 8.3 & 7.7 & 5.2 & 1.9 \\
\hline 100 & 7.5 & 6.9 & 6.2 & 3.8 & 1.4 \\
\hline 500 & 3.9 & 3.3 & 3.9 & 1.7 & 0.6 \\
\hline 1000 & 2.8 & 2.4 & 2.0 & 1.2 & 0.4 \\
\hline 5000 & 2.4 & 1.8 & 1.0 & 0.7 & 0.2 \\
\hline 10,000 & 2.3 & 1.7 & 1.0 & 0.7 & 0.2 \\
\hline 50,000 & 2.3 & 1.7 & 1.0 & 0.7 & 0.2 \\
\hline
\end{tabular}

(a) 800 MWt is NPDES limit; 600 to 650 MWt is normal condition.

TABLE 2. Increase in Columbia River Temperature Assuming Complete Mixing and No Other Thermal Losses/Gains $\left({ }^{\circ} \mathrm{F}\right)$

\section{River Flow Rate (cfs)}

36,000

54,000

72,000

90,000

108,000

126,000

144,000
Thermal Load

\begin{tabular}{cr}
800 MWt & 3000 MWt \\
(N Reactor Only) & (N Reactor and HGP) \\
\hline
\end{tabular}

0.34

1.27

0.23

0.85

0.17

0.63

0.14

0.51

0.11

0.42

0.10

0.37

0.08

0.32 

PHYSCAL FACTORS AFECIING RIVR TEMPERATURE

Solar radiation provides the major source of heat to the Columbia River in the Hanford Reach. Thermal discharges from $\mathbf{N}$ Reactor and the HGP also provide definable sources of heat to the river. River temperatures at Richland tend to be higher than those at Priest Rapids Dm during the warmest river temperature months of July-September because of heat additions resulting from solar radiation and thermal discharge to the river. A general warming trend is noted even in the absence of reactor operation. For example, temperature increases up to $1.4^{\circ} \mathrm{F}$ can occur in the Hanford Reach during late summer as the result of natural heating (Jaske and Synoground 1970). This trend is reversed in the winter months because of heat losses from the river to the atmosphere.

A comparison of the daily mean temperatures at Richland and at Priest Rapids Dam from July 1 to September 29, 1985, indicates a seasonal trend in water temperatures that is related to solar radiation (Figure 1). River temperatures at Richland exceeded those at Priest Rapids Dam during July, August, and the first week in September. During the latter part of September, the air temperatures were lower than the water temperatures, resulting in heat loss from the river to the atmosphere. During this period, river temperatures at Richland became lower than those measured at Priest Rapids Dam. Large fluctuations in river temperatures also occur each day. These differences are caused mainly by daily air temperature fluctuations.

The river temperature will tend to approach an equilibrium temperature (i.e., heat loss or gain) that is a function of the difference between atmospheric temperature and water temperature. However, because of the large diurnal and daily fluctuations in air temperatures, the equilibrium temperature is constantly changing. Daily fluctuations in air temperatures also result in fluctuations in heat gains or losses. Additional thermal loading to the river from the $\mathbf{N}$ Reactor and HGP tends to increase heat losses from the river to the atmosphere when the river temperature is higher than the equilibrium temperature, and to decrease atmospheric heat gains to the river when the river temperature is less than the equilibrium temperature. Thus, a natural 


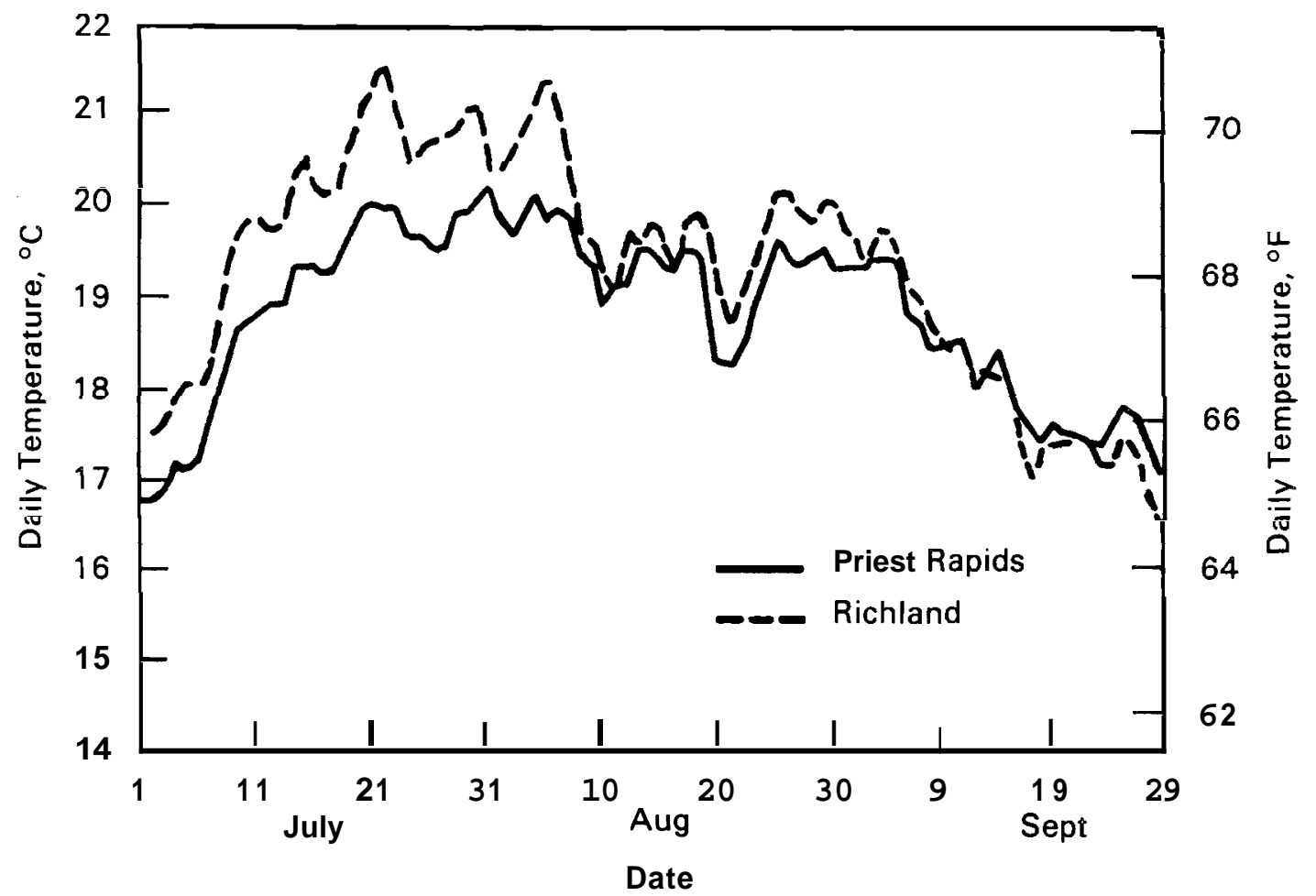

FIGURE 1. Comparison of River Temperatures at Priest Rapids

Dam and Richland, Washington, during July 1 through September 29, 1985

moderating effect on temperature occurs when additional heat loads are discharged to the river. At some point downstream, the additional thermal loading will be dissipated because of this moderating effect.

Studies of the thermal dissipation of reactor effluents indicate that the majority of the heat is dissipated to the atmosphere before the confluence of the Snake and Columbia Rivers (Jaske and Synoground 1970). When nine nuclear reactors were operating at Hanford, $65 \%$ of the reactor heat load had dissipated at the Oregon-Washington border. Additional thermal loading or cooling can occur in the Columbia River following mixing with the Snake River. For example, the mean modification of the Columbia River by the Snake River will be about $0.5^{\circ} \mathrm{F}$ when the average temperature of the Snake River is $1.5^{\circ} \mathrm{F}$ higher, given a flow ratio of 2 between the rivers. However, because of dilution, the Snake River will also reduce the incremental temperature increase resulting from reactor operation. Maximum $\Delta T$ s a t McNary Dam, 
attributable to operation of $\mathrm{N}$ Reactor and the HGP, would be $\angle 0.1^{\circ} \mathrm{F}$ or $0.3^{\circ} \mathrm{F}$ following dissipation of heat loads at Columbia River flows of 144,000 or $36,000 \mathrm{cfs}$, respectively.

The increased thermal atmospheric heat loading (caused by increased surface area and decreased water movement) of Lake Wallula also outweighs the heat load resulting from the combined thermal discharges. Large unstratified reservoirs, such as John Day, tend to wam the river during the summer because of the increase in travel time and the approach to equilibrium between the river temperature and air temperature. Passage through the Columbia River Gorge modifies the water surface to more natural conditions, and heat transfer rates increase because of increased turbulence, thus providing greater cooling (Jaske and Synoground 1970). 



\section{POIENIIAL EFFECTS OF NOREASED THERMAL LOADNG ON DOWNSTREAM FISH POPULATIONS}

Columbia River temperatures below the confluence of the Columbia and Snake Rivers could be increased by a maximum of $0.3^{\circ} \mathrm{F}$ because of the combined effects of the $\mathrm{N}$ Reactor and HGP discharges. This potential increase is realized under worst-case conditions of minimum low flow $(36,000 \mathrm{cfs})$ and assuming 65\% dissipation of effluent heat to the atmosphere. Increased temperatures caused by the $\mathrm{N}$ Reactor discharge alone would be $<\mathrm{O} . \mathrm{I}^{\circ} \mathrm{F}$. The minimum flow scenario is unlikely to occur because of factors that include bank storage in the Hanford Reach and influence of the McNary pool on river flows below Richland. These additional factors would reduce the potential incremental temperature increase that is attributable to reactor operations.

Laboratory studies indicate that lethal temperatures for extended exposure times $\left(>72 \mathrm{hr}\right.$ ) to migrating adult salmonids range between $69.8^{\circ} \mathrm{F}$ to $72.0^{\circ} \mathrm{F}$ (Coutant 1970). The range of thermal tolerance was related to acclimation temperature, with increased tolerance noted for higher ambient river temperature. Therefore, under conditions of high seasonal water temperatures, the higher tolerance value is appropriate for our evaluation. Potential for adult fish mortality caused by excess temperatures would likely occur only during periods of sustained high river temperatures $\left(>71^{\circ} \mathrm{F}\right)$. Mean daily maximum temperatures rarely exceed $68^{\circ} \mathrm{F}$ in the Columbia River at Hanford. The incremental temperature increase caused by $\mathrm{N}$ Reactor operation would not adversely impact adult salmonids.

Measurable increases in river temperature can sometimes result in delays in adult migration. Upstream migration of adult salmonids may be impeded when ambient river temperatures exceed $70^{\circ} \mathrm{F}$ (Fish and Hanavan 1948; Major and Mighell 1967). However, salmon have entered the Snake River from the Columbia River when the temperature of the Snake River exceeded $70^{\circ} \mathrm{F}$ (Snyder and Blahm 1971). Thus, incremental increases less than or equal to $0.3^{\circ} \mathrm{F}$ are unlikely to inhibit adult salmonid migration at locations below $\mathrm{N}$ Reactor.

Ambient Columbia River temperatures during peak juvenile migration (May-June) are $10^{\circ} \mathrm{F}-20^{\circ} \mathrm{F}$ lower than late summer temperatures. In addition, 
juvenile salmonids are generally less sensitive to heated effluents than adults. According to Brett (1952), ultimate upper thermal 1imits (where 50\% of a test population die after I-week exposure) ranged from $74.8^{\circ} \mathrm{F}-77.2^{\circ} \mathrm{F}$ for juvenile salmonids, depending on species and acclimation temperature. Therefore, even juvenile salmonids that migrate in late summer would not be vulnerable to increased thermal effects unless ambient river temperature exceeded $7^{\circ} \mathrm{F}$ for extended periods.

In conclusion, the incremental temperature increase caused by reactor operations is largely dissipated and is masked by diel temperature fluctuations that result from solar radiation and convection cooling. Because the temperature increase is less than $0.3^{\circ} \mathrm{F}$ under all flow scenarios, it is unlikely that $\mathrm{N}$ Reactor operation will adversely impact downstream fish populations. 


\section{REFERENCES}

Brett, J. R. 1952. "Temperature Tolerance in Young Pacific Salmon, Genus Oncorhynchus." J. Fish. Res. Bd. Canada. 9:265-323.

Coutant. C. C. 1970. Thermal Resistance of Adult Coho (Oncorhynchus kisutch) and Jack Chinook (0. tshawytscha) Salmon, and Adult Stee Thead Trout (Salmo gairdneri) from the Columbia River. BNWL_1508, Pacific Northwest Laboratory, Richland, Washington.

Ecker, R. M., W. H. Wal ters and F. L. Thompson. 1983. N Reactor Thermal Plume Characterization Study During Dual-Purpose Mode ot Operation. Part 1. - Field Investigation, Part II - Computer Simulation. Prepared for UNC Nuclear Industries, Inc. by Pacific Northwest Laboratory, Richland, Washington.

Fish, F. C., and M. G. Hanavan. 1948. A Report Upon the Grand Coulee Fish Maintenance Project, 1939-1947. Special Sc1entitic Report No. 55, U.S. tish and Wildlife Service, Washington, D.C.

Jaske, R. T., and M. 0. Synoground. 1970. Effect of Hanford Plant Operations on the Temperature of the Columbia River 1964 to Present. BNWL=1345, Pacific Northwest Laboratory, Richland, Washington.

Major, R. L., and J. L. Mighel1. 1967. "Influence of Rocky Reach Dam and the Temperature of the Okanogan River on the Upstream Migration of Sockeye Salmon." U.S. Fish and Wildlife Service, Fish. Bull. 66:131-147.

Snyder, G. R., and T. H. Blahm. 1971. "Effects of Increased Temperature on Cold-water Organisms." J. Water. Pollut. Control Fed. 43:890-899. 

APPENDIX

DESCRIPTION OF THERMAL MIXING REGIMES AND DOWNSTREAM EXTENI OF N REACTOR PLUME 



\begin{abstract}
APPENDIX
The computer model used to simulate the $\mathrm{N}$ Reactor thermal plume was developed to address the intermediate field or area defined as the zone in which river processes dominate plume dynamics. Thus, heat transfer to the river bank and to the atmosphere is considered negligible. The model solves the classic pseudo three-dimensional, advection-diffusion equation with the following assumptions:

- buoyancy effects are insignificant

- eddy diffusivities are homogenous, but possibly anisotropic

- downstream diffusion is insignificant compared to downstream advection

- the flow is steady, uniform, and one-dimensional.

In addition, the simulated region considered only a fraction of the entire river to isolate the $\mathbf{N}$ Reactor plume from the HGP plume.
\end{abstract}





\section{DISTRIBUTION}

No. of

Copies

OFFSITE

3 DOE Technical Information Center

\section{ONSITE}

DOE Richland Operations Office

J. J. Sutey

30 Westinşhouse Hanford Company

E. M. Greager
No. of

Copies

19 Pacific Northwest Laboratory

K. A. Borgeson

D. D. Dauble

D. W. Dragnich

R. M. Ecker

M. J. Graham

J. M. Hales

P. C. Hays

D. A. Neitzel

T. L. Page

J. A. Stottlemyre

L. W. Vail

R. E. Wildung

Publishing Coordination (2)

Technical Report Files (5) 
